\title{
The use of rootstocks for European (Prunus domestica) and for Japanese (Prunus salicina) plums (review)
}

\author{
Czinege, A. ${ }^{1}$, Soltész, M. ${ }^{1}$, Nyéki, J. ${ }^{2} \&$ Szabó, Z. ${ }^{2}$ \\ ${ }^{1}$ Collage of Kecskemét, Faculty of Horticulture, H-6000 Erdei Ferenc tér 1-3. \\ ${ }^{2}$ University of Debrecen, Centre of Agricultural Sciences and Engineering, Faculty of Agricultural and Food \\ Sciences and Environmental Management, H-4032 Debrecen, Böszörményi str. 138.
}

\begin{abstract}
Summary: The worldwide tendency to increase the intensity of fruit growing technologies prefers generally for every fruit species rootstocks with week or mediocre vigour. From this viewpoint, the use of rootstocks for plums are rather unilateral in Hungary, where 95-99\% of plum plantations are grafted on mirobalan seedlings (P. cerasifera v. mirobalana). The score of plum rootstocks abroad is much more diversified. The present study summarises the respective knowledge referring to the literature available.
\end{abstract}

Key words: rootstock, Eurapean plum, Japanese plum

\section{Introduction}

In Hungary, the most used rootstocks for plums are seedlings of mirobalan trees selected at Cegléd ('C 162', 'C. 174', 'C. 359', 'C.679') first of all for European plums. The main reason of this practice is the generally introduced mechanical harvest, which needs strong trees planted at distances suitable for the machines. On the contrary, the market of fruits for fresh consumption needs manually harvested larger fruits, which are grown on relatively small trees with moderate vigour and are highly productive (Hrotkó, 1999).

Worldwide, the main species of plum rootstocks is the bullace $(P$. insititia) or local plum varieties ( $P$. domestica), even seedling of grown commercial plum varieties, or the Marianna plum (P. cerasifera $x$ P. munsoniana). In France, the Marianna plum is recommended for less fertile soils, where the trees start quickly to yield and are fertile (Hrotkó, 1999). In Poland, also mirobalan seedlings and Wangenheim rootstocks are preferred (Swierczynski \& Stachowiak, 2009).

According to Webster \& Wertheim (1993 cit. Swierczynski \& Stachowiak 2009) rootstocks multiplied vegetatively are 'Pixy', 'GF655/2' and 'St Julien A' being used for intense growing technologies.

\section{A survey of plum rootstocks}

\section{Mirobalán rootstocks (Prunus ceresifera)}

In Hungary, it is the most used rootstock for plums. It is for dry growing sites recommended, but also often used on humid sites, where the grafts are threatened by early frost because the tardive vegetation (Probocskai, 1959).
The species has many variants and is adapted to diverse habitats. Some forms grow sproutss. Most plum varieties are compatible with mirobalan except some Raineclauds and e.g. the variety 'Ruth Gersetter'. Most varieties grow on mirobalan rootstock vigorously or even too vigorously and begin fruiting too lately. Its fertility is satisfactory, but the population of seedlings is heterogeneous (Tóth \& Surányi, 1980; Hrotkó, 1999). Two variants are used of that species: $P$. cerasifera var. cerasifera. cv. myrobalana is used in Europe, whereas var. divaricata is mainly known in East-Europe and in Central Asia (Hrotkó \& Magyar, 2006).

According to Hrotkó (1999) it is used in Hungary for plum varieties at a rate of $95-99 \%$, for apricots at $30-40 \%$. The majority of seed is produced at Cegléd, where the stock plantation is maintained.

According to Rozpara \& Grzyb (1998 cit. Swierczynski \& Stachowiak, 2009), the mirobalan seedlings are vigorous, the graft grow fast but start yielding lately and yields are scarce. On the contrary, in Lithuania profuse yields are achieved (Lanauskas, 2006).

For vigorously growing plum varieties this rootstock is not recommended (Swierczynski \& Stachowiak, 2009). Sosna (2004) proposed its use for light soils.

\section{Seedlings of Mirobalan}

\section{Mirobalan 'C 162'}

According to an earlier indication of Hrotkó (1999), this rootstock is equally recommended for plum as well as for apricot varieties, but there are some apricots, as 'Ceglédi kedves' and 'Ceglédi bíbor' and plums as 'Tuleu gras' and 'Althann ringló' for which it is less suitable. Best yields are 
expected on grafts with 'Magyar kajszi'. For plums 'Stanley' and ' a anska lepotica', the growth was vigorous, and early as well as abundant yields were produced. All the same, it is a vigorous rootstock (Magyar \& Hrotkó, 2006). If week growing varieties are grafted on it, a slender spindle crown training is suitable for intense cultivation. In a successive paper Hrotkó \& Magyar (2006) reported that also for 'Althann ringló' the combination displayed perfect compatibility.

\section{Mirobalan 'C 174'}

As a rootstock for plums it is recommended. Apricot varieties produced heterogeneous growth on its grafts. Its vigour is strong or too strong, it tends to moderate sprouts production (Hrotkó, 1999). 'Tuleu Gras' and 'Montfort' plums seem to be incompatible with it (Hrotkó \& Magyar, 2006).

\section{Mirobalan 'C 359'}

For plums and apricots it is equally recommended. It is the best among the mirobalans for apricot varieties. The trees grow to develop large crowns. Tends to sprouting. Not recommended for plum varieties: 'Tuleu gras', 'Ruth Gerstetter' and 'Althann ringló' (Hrotkó 1999).

\section{Mirobalan 'C 679'}

Producing a vigorous upward striving tree, but some plum varieties are weak growing as grafts: 'Tuleu gras' and 'Ruth Gerstetter' (Hrotkó, 1999).

Japanese plum varieties if virus free, did not show incompatibility at the Cegléd plantations (Surányi et al., 2011).

\section{'Myrobalan A'}

It was selected in Germany from a population of seedlings, as being more resistant to frost then the rest. Multiplication is successful by layering or cutting. Vigorous growth, but incompatible with Raineclauds as well as with 'Ruth Gerstetter' and 'Kirke' varieties. In spite of vigorous growth, starts yielding early and profusely (Tóth \& Surányi, 1980).

\section{'Myrobalan B'}

The grafted tree will be large. For heavy yielding European plums ( $P$. domestica ) but not for Raineclaudes, it is a good rootstock (Probocskai, 1959). Its growth is upward striving and vigorous, but starts yielding later. For the soil it is unassuming. Not recommended for 'Althann ringló' and for varieties of the Mirabella type, having low affinity (Hrotkó, 1999).

Myrobalan B is a selection of England, East-Malling. It is good for soils of low quality too. Multiplication ensues by layering as well as by cutting (Tóth \& Surányi, 1980). According to Hrotkó (1999) it is not easy to grow layers. The growth is vigorous, but not recommended for Raineclaudes. As its vigour is strong, therefore this rootstock should be preferred for varieties of low vigour (Tóth \& Surányi, 1980; Hrotkó \& Magyar, 2006).

In a publication, Rosenberg explained the results of his experiment during the 1980-es, which concluded with the statement that Japanese plums like 'Shiro' and 'Methley' are incompatible with the mirobalan rootstocks (Andersen et al., 2006). Mezzetti \& Sottile (2007) on the contrary maintain the European and Japanese plums are equally successful on Myrobalan stocks.

\section{'MY-BO-1'}

It is a selection of western Slovakia, rated as medium vigorous. Green or wooden cuttings are used for its multiplication, although its seedling population is rather uniform. The inoculation is on this stock easy. The soil preferred is light and warms up quickly. Take care of the roots being susceptible to dry out (Hrotkó, 1999; Magyar \& Hrotkó, 2006).

\section{'MY-KL-A'}

Selection performed in eastern Slovakia from a local population. In the nursery it is easy to recognise by its red leaves and the perfect lack of thorns and easy to multiply by woody and green cuttings. Roots are susceptible to drying out at plantation. It requires good soils and is frost tolerant. The affinity with plums and apricots is satisfactory. The vigour is mediocre, fruiting starts early and yields are abundant. Only the variety 'Althann ringló' grows poorly (Hrotkó, 1999; Magyar \& Hrotkó, 2006).

\section{'Myrobalan 29 C'}

This rootstock is widely used in the USA and Italy for peaches. Green cuttings and micropropagation is a general practice. Vigorous growth and adaptable for different soils and compatible with varieties is typical (Hrotkó, 1999). Suitable for European as well as Japanese plums (Mezzetti \& Sottile, 2007)

\section{'Miro'}

It is suitable for all kind of soils, and the compatibility for all plum varieties is good (Internet 1).

\section{'Myrocal'}

It is a clone of myrobalan selected in France, its compatibility is good for plum varieties vigorous or very vigorous. It is less susceptible to chlorosis and asphyxia of roots (Hrotkó, 1999).

\section{'Corcodus', 'Myrobalan 2 V', 'Myroval'}

Klons, which are selected in Romania as compatible with European plum varieties. Very vigorous growth, but starting 
with early fruiting. Multiplication is performed by woody cuttings (Cисiu et al., 1997, Botu at al., 1998, Achim et al., 2002 cit. Hrotkó \& Magyar, 2006)).

\section{Mirobalan hybrid rootstocks}

\section{'INRA GF 31'}

Bred in France by crossing the east asian P. salicina with myrobalan. The affinity with plums of any species and with apricots is good, but for Raineclaudes not perfect. Multiplication is performed by green and woody cuttings. In Italy, the nurseries use it. Grafts start fruiting soon. To virus diseases it is very susceptible, therefore used as a test plant (Hrotkó, 1999).

At Geneva, it was praised as an abundant yielder (Andersen et al., 2006).

\section{'MRS 2/5'}

In Italy, another interspecific hybrid, $P$. cerasifera $x P$. salicina, is not recommended for non irrigated sites. Cuttings and micropropagation is used for multiplication. It promotes fruit size and colour development positively (Hrotkó, 1999; Hrotkó \& Magyar, 2006).

\section{'Myram'}

Produced in France as a triple hybrid of ( $P$ cerasifera $x P$ salicina) $\mathrm{x}$,Yunnan” peach. As rootstock it suits for almond, peach and plum. Vigorous growth, planted preferably to humid and heavy soils.. It is susceptible to chlorosis (Hrotkó, 1999; Hrotkó \& Magyar, 2006).

\section{'Citation'}

Also a hybrid of Prunus salicina x Prunus persica. Obtained in America. The coloured leaves make it easily recognised in the nursery. The dwarfing effect reduces its vigour. It is susceptible to high water table and to excessive chalk content of soils. Buds burst a bloom open rather late and the plant enters early into deep rest period. (Hrotkó, 1999).

\section{'Ishtara'}

As a hybrid of myrobalan and Japanese plum, it appeared in France. It is used mainly for European plums, but Japanese plums, apricots, peaches and almond varieties are also growing well. As a rootstock it is weaker than myrobalan, thus semi dwarfing. On humid soils, asphyxia of roots is threatening. Trees turn yielding early (Hrotkó 1999, Hrotkó \& Magyar, 2006).

'Ishtara' and 'GF 655/2' as rootstocks produced trees of similar size on 'Stanley' grafts in Bohemia. 'Valjevka' grafts were outstanding in fertility. Sprouts did not appear yet (Kosina, 2007).

\section{'Prumina', 'Ferlenain'}

They appeared in France as hybrids between $P$. bessey $x P$. cerasifera. The growth of grafted trees is effectively reduced. It is resistant to drought, chalk and frost. The roots support the trees weakly and sprouts appear (Hartmann, 1984; Okie, 1987; Cociu et al., 1997 cit. Hrotkó \& Magyar, 2006).

\section{'Micronette'}

An interspecific hybrid appeared in Germany between $P$. pumila $x P$. cerasifera. Growth is effectively reduced and the resistance to drought, chalk and frost is remarkable. Poor support of roots in the soil and appearing of sprouts are its negative traits (Hartmann, 1984; Okie, 1987; Cociu et al., 1997 cit. Hrotkó \& Magyar, 2006)).

\section{'Krymsk ®1' (VVA-1)}

Made in Russia 1966 as a hybrid of $P$. tomentosa $x P$. cerasifera. Grafts are less vigorous than those grafted to ' $\mathrm{St}$. Julien A' and yields also more. High chalk content is hardly tolerated (Whertheim \& Kemp, 1998; Balkhoven et al. cit Hrotkó \& Magyar, 2006).

Since 1994, regular experiments dealt with this rootstocks in Netherland. Varieties 'Avalon', 'Excaluibur', ' Jubileum', 'Opal', and 'Victoria' were compatible. Compared with other rootstocks, 'Ferlanain', 'Otesani' and 'Pixy', this was the most dwarfing rootstock, turned to yielding and profusely yielding (Maas et al., 2011)

Size of the trees was reduced by $40-50 \%$. As rootstock it was used for peach, nectarine, most European plums, apricot successfully. Dependable yields are expected, provided when irrigated at dry sites. Green and woody cuttings are rooting well (Internet 2).

\section{'Krymsk 86'}

A hybrid of Prunus persica $x$ P. cerasifera. Regarding the vigour of growth, its effect is similar to that of myrobalan. Compatible with almonds, peaches, apricots and European plums. Tolerating humid and heavy soils too, it is less susceptible to winter frosts. The trees start fruiting early and the size of fruits is growing. Multiplication is performed easily by green and woody cuttings (Internet 2).

\section{'Krymsk 2'}

A hybrid of Prunus incana x $P$. tomentosa, reduces the size of trees by $40 \%$. Most plum varieties are compatible with it. They yield profusely. Dry growing sites and frosty habitats are tolerated. It is multiplied by green and woody cuttings (Internet 2 ).

\section{Marianna type rootstocks for plums}

P. cerasifera $x$ P. munsoniana hybrids are as rootstock vigorous. The roots are susceptible to frost. It is compatible 
with most plum varieties except 'President' and 'Cár', which start growing scarcely if inoculated. Start of yielding is early, yields are abundant, fruit quality is excellent (Tóth \& Surányi, 1980).

\section{'Marianna GF 8-1'}

A selection made in France in a seedling population. It is tolerant to soils, multiplied by cuttings. Plum varieties are compatible with it except 'Althann ringló' being controversial (Tóth \& Surányi, 1980), but under conditions of Szigetcsép, the grafted trees were healthy. Yields were profuse. As a substitute for myrobalan seedlings, it could be used successfully. (Hrotkó \& Magyar, 2006; Magyar \& Hrotkó, 2006).

Jänes \& Pae (2003) reported that the grafted trees grew to large trees in Estonia and the highest flower density was experienced. At Geneva, the profuse yields and a tendency to grow sprouts have been registered (Andersen et al., 2006)

It is more tolerant to dry and poor soils than myrobalan, its winter tolerance is not defined. Some chalk tolerance has been stated. It is susceptible to nematodes (Internet 1). Compatible with European as well as with Japanese plums (Mezzetti \& Sottile, 2007).

\section{'Marianna 4001'}

At Geneva it excels with its profuse yields. It is inclined to produce sprouts (Andersen et al., 2006).

\section{Prunus insititia-rootstocks}

\section{Bullace}

In central Hungary, in the region between the rivers Danube and Tisza, bullace was used as rootstock, but grafts are made on it with peaches and almonds. Its advantage was the shorter vegetation period compared with that of myrobalan, which means that on humid soils it was the preferable rootstock. The grafts are longer living and rooted deeper. Sprouts are less frequent. Grafts (inoculated) start growing slower than on myrobalan and to the fungal diseases it is more susceptible (Probocskai, 1959).

In France and Germany it is an important rootstock for plums. It is adapted to cool and humid growing sites. Multiplied by seeds, the population is less homogeneous. As rootstock, it is considered to be mediocre regarding vigour, but the trees are not uniform (Tóth \& Surányi, 1980).

\section{'C83 Kökényszilva'}

A rootstock of medium vigour (Hrotkó, 1999).

\section{'St Julien A'}

As a selected seedling it was obtained in England, EastMalling. Compatible with the European plum varieties, but it is used for peach and apricot too. The size of grafted trees is mediocre and they turn fruiting early. Multiplication is performed by cuttings, which take roots easily and inoculations are successful. It is susceptible to drought and to winter temperature minima. For planting the spring is recommended (Probocskai, 1959). Tóth \& Surányi (1980) multiplied it also by layering. Inoculated plants developed few branches in the nursery (Hrotkó, 1999). According to Lanauskas (2006) the size reduction of the grafts was $6 \%$ only compared with myrobalan rootstocks.

\section{'INRA St Julien GF 655/2,}

As a rootstock for peach and plum, it is widely used. Its affinity with plums and Raineclaudes is good. It is multiplied by woody and green cuttings. Its growth is upward striving, but the grafts grow with reduced vigour, start yielding early. Sprouts are not or only scarcely produced. Soil quality does not cause problems, chalky and dry site are tolerated. Also recultivation is possible with this rootstock. When planting, drying out of roots is a susceptible danger. In Hungary, the winter hardiness is acceptable (Hrotkó, 1999; Magyar \& Hrotkó, 2006). Jänes \& Pae (2003) reported from Estonia that grafts on 'St Julien GF 655/2' bloom profusely, but yields were modest. As a rootstock for peach and plums, it grows with moderate vigour and profuse yields. Heavy and humid soils are satisfactory for it. Resistance is found to Phytophtora (cactorum) and bacterial canker (Internet 1). Compared with myrobalan, the reduction of vigour is about $10 \%$. Sprouting potential is observed by Lanauskas (2006). Observations in Czechia prove its sprouting potential (Kosina, 2007)

\section{'St Julien Wädenswill'}

In Estonia, 'St Julien Wädenswill' proved to be the less vigorous rootstock, where the trees developed the most narrow crown and reduced the growth by $50 \%$ compared with grafts with 'Marianna GF 8-11' rootstocks. Blooming intensity and fruit set were both weak (Jänes \& Pae, 2003).

\section{'St Julien d'Orleans'}

According to reports from Estonia, a profuse blooming (number 4 on the scale of 1-5) high yields were measured. Multiplication is performed by seeds. The vigour of the grafts was mediocre with the varieties 'Queen Victoria' and 'Kubenskaya Kometa' (Jänes \& Pae, 2003).

\section{'St Julien INRA 2'}

It is a semi dwarfing rootstock multiplied by seed. After a profuse blooming (on a scale 4) dependable yields are produced (Jänes \& Pae, 2003).

\section{'Pixy'}

It is selected in England East-Malling from the seedlings of 'St Julien'. Affinity with plums and Raineclaudes is good. 
Its vigour is weak. Grafts are starting to yield early but on the aging tree the fruits get smaller. Multiplication ensues by green and woody cuttings (Hrotkó, 1999).

According to Czech experiences, the fruit size diminished on the grafted rootstocks. Sprouts are not produced (Kosina, 2007).

\section{'INRA Damasd 1869'}

A clone selected from the variety of that name. For soils with high chalk content it is recommended. Its vigour is mediocre, strongly sprouting. Its affinity with nectarines is poor (Hrotkó, 1999; Hrotkó \& Magyar, 2006).

\section{'Otesani 11'}

This clone originated in Rumania. Woody cutting and micropropagation are the tools of its multiplication. Affinity with plum varieties is good. It is especially for heavy soils recommended (Cociu et al. 1997; Botu et al., 1998, Botu \& Achim, 2002 cit. Hrotkó \& Magyar, 2006). It is of semi-dwarf growth compared with 'Pixy' or 'Saint Julien A', but also for very heavy clay soils adapted. Its affinity is the best even for 'Tuleu gras' and 'Althann ringló' varieties. Woody cuttings are recommended especially combined with soil heating (Internet 3).

\section{St Julien damascena 'Noir'}

It is multiplied by seeds..

\section{Plum rootstocks (P. domestica)}

In Hungary plums are seldom used as rootstocks, however, abroad it is much more the case. Seedings of 'Wangenheim' are used in Poland, the 'Zöld ringló' and 'Ageni' all over the world. 'Ackermann' seedlings in Germany, Poland, Czechia. In Rumania, 'Otesani 8' and 'Rosior varatic' seedlings are utilised. Long ago plum varieties were used also in Hungary as 'Vörös szilva', 'Bódi szilva' or 'Fosóka'. Seeds of the most known variety 'Besztercei' are difficult to raise, and the time when inoculations could be performed is very short. Perhaps that is the reason why the habitude to multiply trees by seeds could not be maintained. By all means they would be good rootstock for humid and cold sites (Hrotkó, 1999; Hrotkó \& Magyar, 2006).

\section{'Brompton'}

It is more frost tolerant than of myrobalan. Multiplication is performed by seed, layering, and by cuttings. The growth vigour is strong, the grafts too. Compatibility is good, but the turns to yield a little later (Tóth \& Surányi, 1980).

The selection was performed in England, but it is spread over Europe. The affinity with varieties is satisfactory. Woody cutting are made successfully. Heavy soils are promoting root goitres (Hrotkó, 1999). For double grafts it is utilised as the trunk.

\section{'Black Damas'}

As a selection from a population of seedlings it is multiplied by layering with filling up. Its cold tolerance is not perfect. Its compatibility is good with. Its vigour is strong and yields profusely (Tóth \& Surányi, 1980).

\section{'Lószemű szilva'}

In Hungary it is known as a rootstock for apricots. The typical, asphyxia of apricot trees is told to be less threatening with this than with the wild apricot understock. Long living trees are resistant to drought (Probocskai, 1959).

\section{'Bódi szilva'}

In Hungary it is known as rootstock for apricots. A vigorous sprouting is typical (Probocskai, 1959).

\section{'Besztercei szilva' - 'Fehér besztercei'}

Also for apricots is recommended as producing long living trees (Probocskai, 1959), but also for plums with good compatibility. The size of the trees is reduced with its weak or semi vigorous growth. It is multiplied by green cuttings. The young plants may easily exsiccate. Recommended only for good soil conditions (Hrotkó, 1999).

The vigour is weak, and the yields tend to be poor yielder (Magyar \& Hrotkó, 2006).

\section{'Kisnánai lószemü'}

As plum rootstock it is known in Hungary, which has been used mainly for apricot varieties (Hrotkó, 1999).

\section{'Ackermann'}

Earlier it was used as rootstock in Germany. Multiplied by layering. Frost susceptible on light soils Korábban Németországban használták alanynak. Bujtással szaporítható. Laza talajon fagyérzékeny. It compatibility is controversial on sandy soils. Growing vigour is mediocre (Tóth \& Surányi, 1980).

\section{'Cammon Plum'}

It is multiplied by root sprouts and layering. Compatibility is good with Raineclauds, but incompatible with varieties „Cár” and „President”. It is medium vigorous, turns yielding early and is fertile as in its grafts (Tóth \& Surányi, 1980).

\section{'Wangenheim'}

It is an old German variety multiplied by seed. In Poland, the grafts are semi-vigorous or half-dwarf. For plums and Raineclaudes, the compatibility is good. They turn yielding early és are fertile. Cold tolerance and winter hardiness is 
satisfactory, the root system is firm in spite of its modest vigour (Hrotkó, 1999). Jänes \& Pae (2003) considered it as weakly vigorous. The trees start yielding earlier and more profusely than on myrobalan rootstocks. Fruits of some varieties get smaller especially on light soils (Gryzb et al., 1998, 2000 cit. Swierczynski és Stachowiak, 2009).

\section{'Wavit'}

As a result of selection in Prunus domestica,,Wangenheim” seedlings is multiplied in Austria for its positive properties. It combines advantages of the well known Wangenheim seedlings. The grafts on the uniform seed population turn to yielding early and yield profusely. The fruit are on the grafts large and ripen a little earlier. Compatibility with plums and apricots is good. (Internet 1).

\section{'Otesani 8',}

Semi-dwarf rootstock selected in Rumania with good compatibility for Europan plums and Raineslaudes. Any soil types are suitable, starts yielding early, and is fertile. Its propagation ensues by woody cuttings but also by deeds. (Cociu et al., 1997, Botu et al., 1998, Achim et al., 2002 cit. Hrotkó \& Magyar, 2006)).

\section{'Penta' and 'Tetra'}

Those are plum rootstocks bred in Italy multiplied vegetatively. For the soil they are tolerant, but prefer heavy soils, where they grow better even without irrigation. Cutting and micropropagation are made (Nicotra \& Moser, 2002; cit. Hrotkó \& Magyar, 2006).

\section{'Sharpe'}

Origin unknown. The vigour is moderate also mainly for peaches. Flowers are small and white. Fruits are small (3-4 cm diameter), yellow skin and flesh. Multiplication was done by green and woody cuttings. Trees grafted on 'Sharpe' rootstock are substantially smaller than on Guardin grafts, and the yields are also lower (Beckman et al., 2008).

\section{'Flordaguard'}

It is a cold-tolerant plum rootstock, which also suits for peach, nectarine too. Grafts start early yielding. Its flowers are autofertile, and it is multiplied by seeds. Branches are flexible. High chalk content of the soil is intolerable. The red leaves distinguish it in the nursery. Resistant to nematodes. Its chilling requirement is 300 hours (Internet 4).

\section{'Nemaguard'}

Its chilling requirement is 825 hours, the leaves are green, and it is resistant to nematodes (Internet 4).

\section{Other rootstock varieties for plums}

\section{'Zöld ringló' ( $P$. italica)}

Its clones are multiplied by sprouts and layering outside from Hungary. It is a vigorous rootstock, starts yielding early, yields are outstanding. The tree is long living due to its rootstock effect. The compatibility relations are good (Tóth \& Surányi, 1980).

\section{’Jaspy ${ }^{\circledR}$ Fereley' (P. salicina $x$ P. spinosa)}

It is an interspecific hybrid for heavy soils with poor aeration. The vigour is mediocre, tolerates high chalk content, holds fast in the soil, compatible with European plums including Raineclaudes. Start of yielding is early and fertility is profuse (Hrotkó \& Magyar, 2006). As rootstock is suitable for Japanese plums too (Mezzetti \& Sottile, 2007).

Compared with 'Marianna GF 8-1', the trees are stronger by $10-20 \%$, therefore it belongs to the vigorous hybrid (Hrotkó, 1999). The variety 'Stanley' grows weaker than on 'GF 655/2' rootstock. ' a anska lepotica' and 'Stanley' plums yield profusely in experiments performed in Czechia (Kosina, 2007). They start yielding early. Affinity also with Raineclaudes is good. It is recommended first of all for plums, but it is also good for apricots and peaches (Hrotkó, 1999).

\section{Homoki meggy (Prunus bessey)}

An excellent rootstock with frost and drought resistance, raised from seed and root sprouts. As rootstock it is compatible with plum varieties except „Viktoria”. It is a really dwarfing rootstock, and the graft starts yielding profusely (Tóth \& Surányi, 1980).

However, Jänes \& Pae (2003) stated that it is incompatible with plum varieties, susceptible to diseases and not recommended as rootstock.

The dwarf growth allows crowns of $30 \mathrm{~m}^{3}$ volume and $10 \mathrm{~m}^{2}$ projected area with $100 \mathrm{~cm}^{2}$ cross section area of the trunk (Botu et al., 2002).

\section{Pelyhes meggy (Prunus tomentosa)}

According to Polish sources, grafts grew less vigorously the on myrobalan rootstocks ( $P$. cerasifera). The tree size was reduced by $25 \%$, but the accumulated fruit yield was significantly higher (Swierczynski \& Stachowiak, 2009).

\section{The types of planting material as grafts}

Plum trees may be ready for planting as saplings without branches, but also with primary branches in the first or in the second year, and also as "Knipp-baum". Advantage of the sapling and the crown of the first year is the small root system, which could be lifted with little mutilation from the nursery. It is easy to raise a slender spindle as the most 
practical crown for intense technology. On the other hand, plants with branches start yielding earlier than saplings.

The 2 year old grafts are ready for planting and suitable to be trained to an open crown. The slender spindle crown needs to have the leading shoots bound down, because the narrow ramification may easily split during the next years. The Knipp-tree has a grafted crown, with a renewed trunk. It means that the roots are 3 year old, the larger part of the trunk is 2 year old and the upper part, including shoots, is 1 year old. The shoots are branches of secondary or sylleptic ramifications and tend to be nearly horizontal. Thus the conditions of the slender spindle are given.

For apricot trees, also grafts composed by three constituents are trained, where the root is myrobalan, the trunk is a plum in turn grafted in the crown to an apricot variety. The advantage of this composition is a healthy trunk.

The summary and comparison of plum rootstocks known from the literature according to their growing vigour is presented in Table 1.

Table 1. Rootstocks for plums according to their growing vigour

\begin{tabular}{|c|c|c|c|c|}
\hline $\begin{array}{l}\text { Weakly } \\
\text { growing }\end{array}$ & $\begin{array}{c}\text { Between } \\
\text { weak and } \\
\text { mediocre } \\
\text { growth }\end{array}$ & $\begin{array}{l}\text { Mediocre } \\
\text { vigour }\end{array}$ & $\begin{array}{l}\text { Vigorous } \\
\text { growth }\end{array}$ & $\begin{array}{c}\text { Very } \\
\text { vigorous }\end{array}$ \\
\hline $\begin{array}{l}\text { Cerasus } \\
\text { bessey } \\
\text { 'Prumina' } \\
\text { 'Ferlenain' } \\
\text { 'Micronette } \\
\text { 'Krymsk 1' } \\
\text { Prunus } \\
\text { spinosa }\end{array}$ & $\begin{array}{l}\text { 'Otesani 8' } \\
\text { 'Citation' } \\
\text { 'Ishtara', } \\
\text { 'Fehér } \\
\text { besztercei' } \\
\text { Wangenheim }\end{array}$ & $\begin{array}{l}\text { 'Otesani 11' } \\
\text { 'MY-BO-1' } \\
\text { 'MY-KL-A' } \\
\text { 'rootstocks } \\
\text { 'Kökényszilva- } \\
\text { C83' } \\
\text { 'St Julien A' } \\
\text { 'St Julien } \\
\text { GF 655/2' } \\
\text { 'St Julien } \\
\text { d'Orleans' } \\
\text { 'St Julien I } \\
\text { NRA2' } \\
\text { 'INRA } \\
\text { Damasd 1869' } \\
\text { 'Pixi', } \\
\text { 'Ackermann' } \\
\text { 'Cammon } \\
\text { plum' } \\
\text { Prunus } \\
\text { tomentosa }\end{array}$ & $\begin{array}{l}\text { 'Myrobalan } \\
29, \\
\text { 'Myram' } \\
\text { 'Brompton' }\end{array}$ & $\begin{array}{l}\text { 'Marianna } \\
\text { GF 8-1' } \\
\text { Mirobalan } \\
\text { 'C162', } \\
\text { 'C174', } \\
\text { 'C359', } \\
\text { 'C679' } \\
\text { 'Myrocal' } \\
\text { 'Corcodus,' } \\
\text { 'Myrobalan } \\
\text { 2', } \\
\text { 'Myroval' } \\
\text { 'Jaspi } \\
\text { Fereley' } \\
\text { 'Krymsk 86' } \\
\text { 'Black } \\
\text { Damas' }\end{array}$ \\
\hline
\end{tabular}

\section{Acknowledgement}

Research was sponsored by TECH_08-A3/2-2008-0373 and TECH_08-A4/2-2008-0138 grants.

\section{References}

Andersen R., Freer J. \& Robinson T. (2006): Plum rootstock Trial at Geneva: A progress Report. New York Fruit Quarterly 14(1): 27-28.

Beckman T. G., Chaparro J., \& Sherman W. B. (2008): ,, Sharpe” a Clonal Plum Rootstock for Peach. HortScience, 43 (7): 2236-2237.
Botu et al. (2002): The evaluation and Classification of Growth Vigor of the Plum Cultivars Grafted on Various Rootstocks. Acta Horticulturae 577: 209-306

Hrotkó K. (1999): Alanyhasználat a szilvatermesztésben. [In: Hrotkó K. (szerk.), Gyümölcsfaiskola.] Mezőgazda Kiadó, Budapest, 482-495.

Hrotkó K. \& Magyar L. (2006): A szilva alanyai és szaporitásuk [In: Surányi D. (szerk.), Szilva.] Mezőgazda Kiadó, Budapest, 108-128.

Hrotkó K., Magyar L., Klenyán T. \& Simon G., (2002): Effect of Rootstocks on Growth and Yield Effeciency of Plum Cultivars. Acta Horticulturae 577: 105-110.

Internet 1: www.cdb-rootstocks.com/english/e_produkte_ pflaume_wavit.htm

Internet 1: Wolfe D. E., Strang J. G., Wright S.: Rootstocks for Kentacky Fruit Trees. http://www.ca.uky.edu/agc/pubs/ho/ho82/ ho82.pdf

Internet 2: Eremin. G.: Peach, Plum, Apricot, \& Almond Rootstocks, New Russian Prunus Rootstocks http://www.treeconnect. com/pdfs/krymsk86.pdf

Internet 3: Botu I., Torcu E., Motu M. New Plum rootstocks selections with low vigour and High Capacity of Propagation. http:// www.actahort.org/members/showpdf?booknrarnr=658_65

Internet 4: Fergusson J., Chaparro J.: Rootstocks for Florida Peaches, Nectarines, and Plums, http://edis.ifas.ufl.edu/hs366

Jänes H., Pae A. (2003): First results of a dwarfing plum rootstocks trial. Agronomy Research. 2003:1 (37-44)

Kosina J. (2007): Orchard Performance of Some New Plum Rootstocks in The Czech Republic. Acta Horticulturae 734.

Lanauskas J. (2006): Effect of Rootstocks on Growth and Yield of Plum tree cvs. 'Stanley' and 'Kauno Vengriné'. Scientific Works of Lithuanian Institute of Horticulture and Lithuanian University of Agriculture 25 (3): 243-249.

Maas F. M. Balkhoven \& Baart: (2011): Krymsk® 1 ( VVA-1) A dwarfing rootstock suitable for high density plum orchards in the Netherland. Proceedings of the IX International Symposium on Integrated Canopy, Rootstock and Environmental Physiology in Orchardsó Systems, Geneva, Acta Horticulturae 903.

Magyar L. \& Hrotkó K. (2006): Growth and productivity of plum cultivars on various rootstocks in intensive orchard. International Journal of Horticulture Science 12 (3): 77-81.

Mezzetti B. \& Sottile F. (2007): MI.P.A.F. Targeted Project for Evaluation of Euiropean and Japanese Plum Rootstocks in Italy: Resdults of Six Years of Observations. www.pubhort.org/actahort/ books/734/734_17.htm

Probocskai E. (1959): Faiskola. Mezőgazdasági Kiadó. Budapest. Sosna I. (2004): Oceanawartosci produktcyjnej kilkudziesieciu odmian sliwy na pobkładce ałyczy w rejonie Wrocławia. cit S. Swierczynsky and A. Stachowiak (2009): The usefulness of two rootstocks for some plum cultivars. Journal of Fruit and Ornamental Plant Research 17 (2): 63-71.

Surányi D., Kölber M. \& Szarka I. (2011): Ceglédi alany japán szilváknak. Kertészet és Szölészet, 33.

Swierczynski S. \& Stachowiak A. (2009): The usefulness of two rootstocks for some plum cultivars. Journal of Fruit and Ornamental Plant Research 17 (2): 63-71.

Tóth E. \& Surányi D. (1980): A szilva szaporítása [In: Tóth E. és Surányi D. (szerk.): Szilva.] Mezőgazdasági Kiadó, Budapest, 196-208. 